\title{
THE REVERSE LOGISTICS IMPORTANCE IN THE MANAGEMENT OF RESIDUES OF PLASTIC PACKAGING OF LUBRICANTS AND THE PROGRAM JOGUE LIMPO
}

Everaldo Francisco da Silva Instituto Federal de Educação, Ciência e Tecnologia de São Paulo

E-mail: everaldo_silvaf@globomail.com

Luís Fernando Ferreira Damasceno Instituto Federal de Educação, Ciência e Tecnologia de São Paulo

E-mail: luisfernandofd@yahoo.com.br

Prof. Dr. Luiz Teruo Kawamoto Júnior Instituto Federal de Educação, Ciência e Tecnologia de São Paulo

E-mail: teruo@ifsp.edu.br

Submission: 03/01/2017

Accept: 14/01/2017

\section{ABSTRACT}

This article aims to demonstrate the importance of the Reverse Logistics in the management of solid residues through the Jogue Limpo program, an initiative dedicated to the destination and recycling of lubricant packaging. In the current context, where natural resources are scarce, the environmental issue is a factor of differentiation in business, so the destination of the waste we produce along the production chain and the possibility of reuse and mitigation of possible environmental impacts are extremely important for the society. The article seeks to show how the Reverse Logistics is the means to interconnect stakeholders for the correct destination and reuse of resources, as well as the benefits of this initiative for the society.

Keywords: Reverse Logistics, Jogue Limpo Program, Waste Management, Plastic Packaging, Lubricants. 
DOI: 10.14807/ijmp.v8i5.602

\section{INTRODUCTION}

Over the last years, there is a constant concern for the planet's natural resources and sustainability. The adoption of new techniques, tools, technologies, has contributed significantly in this process. Concern over resource scarcity, pollution of the environment and forms of responsible consumption triggers the concern about the ultimate destination of what remains of the process after consumption.

In this context in particular there are types of packaging that are important that have a differential treatment in their return to the production process and reuse and its correct destination, because it contains products that are highly polluting to the soil and water, for example lubricants, which are oil-derived and in contact with the soil cause enormous environmental damage.

However, the fact that there is currently innovation in environmentally sustainable packaging is not enough if there is not, above all, a waste management policy that can guarantee the tracking of packaging along the consumption chain and the post-consumption return. This management is only possible from the involvement of those responsible for the supply chain that is currently called reverse logistics. The aim of reverse logistics is to promote the set of actions and practices that guarantees the return of waste to the production process and the responsible disposal of what cannot be reused. Initiatives such as the Jogue Limpo program show the reverse logistics in practice.

\section{METHODOLOGY USED}

The report will be done through a case study of a descriptive and qualitative character, since it reports and analyzes the Jogue Limpo program and the value of the reverse logistics in the management of residues of lubricating packaging.

One of the methods for data collection and survey will be based on the use of information about structured and informative interviews with managers and information, conducted through basically two forms: the first one is intended to the survey of characteristics of the Jogue Limpo program and how it performs the reverse logistics, and the second is to investigate the reasons why it is important to implement this program. 
According to Yin (2001), one of the most important sources of information for a case study is the interviews, as this nature of the interviews allows you to both inquire about the facts in a way and ask for their opinion about certain events, and in some situations you may even ask the respondent to present their own interpretations of certain events.

Data collection will also be used based on the method of documentation and records in files for use in conjunction with other sources of information. According to Yin (2001), documents perform an obvious role in any data collection, when conducting case studies, because systematic searches for documents are important in any planning for the survey.

\section{REVERSE LOGISTICS}

To define the concepts that guide Reverse Logistics, it is necessary to understand the meaning of the evolution of the Logistics concept and its importance to the results. According to Moura (1989, p. 26, our translation), it is understood that:

[...] It is possible to define the company's logistic system as the set of resources (manpower, production resources, machines, vehicles, handling and storage elements) employed to physically develop all manufacturing, storage and handling operations, which ensure the flow of materials from the suppliers to the customer ${ }^{1}$.

Logistics can be conceptualized as the part of Supply Chain Management that plans, implements and controls the flow and the efficient and economical storage of raw materials, semi-finished materials and finished products, as well as information about them, from the point of origin to the point of consumption, in order to meet the requirements of customers (CARVALHO, 2002, p. 31).

Until the 80's, the concept of Logistics was only approached about the prism from the raw material, to the end customer, not caring about the waste of this process. With the evolution of Logistics itself as a science, the increase in the structure of operations, processes, tools and indicators to measure the results of Logistics in the organizations, the incorporations of concepts that have transformed

${ }^{1}$ Original: [...] pode-se definir o sistema logístico da empresa como o conjunto de recursos (mão de obra, recursos de produção, máquinas, veículos, elementos de movimentação e armazenagem) empregados para desenvolver fisicamente todas as operações de fabricação, armazenagem e movimentação, que permitem assegurar o fluxo de materiais desde os fornecedores até o cliente. 
information flows and goods in the world, such as the Supply Chain Management, the Lean Manufacturing, the Toyotism, among others, in addition to the advent of concern with the environment, the concept of Logistics was expanded to include all operations from conception, passing through information flows, raw material, manufactured products, passing through the final customer until its correct disposal, reuse or return to the production process.

This phenomenon was conceptualized as Reverse Logistics, the Logistics area that is concerned with the reverse flows of the post-consumer products, the consumer for the correct disposal and the return to the production process.

It is also defined as:

The process of planning, implementing and control of the efficiency and cost effectiveness of the flow of raw materials, process inventories, finished products and the corresponding information from the point of consumption to the point of origin with the purpose of recapturing the value or allocating it to the appropriate layout (ROGERS; TIBBEN-LEMBKE, 1998, p. 2, our translation) ${ }^{2}$.

Reverse Logistics' concern is not only environmental, but also of adding value to the product, or minimizing the use of raw materials incorporating post-consumer waste, and ensuring the proper destination of what can't be reused. For Leite (2003, our translation), Reverse Logistics is:

[...] Such as the area of business logistics that plans, operates, and controls the flow and corresponding logistics information from the return of aftersales and post-consumer goods to the business cycle or production cycle, through reverse distribution channels, adding value to them of various natures: economic, ecological, legal, logistic, corporate image, among others $^{3}$.

Liva et al. (2003) divides Reverse Logistics into three distinct areas:

- Reverse Logistics after sales: responsible for the return flows of products under warranty, or errors of orders, or even returns.

${ }^{2}$ Original: O processo de planejamento, implementação e controle da eficiência e custo efetivo do fluxo de matérias-primas, estoques em processo, produtos acabados e as informações correspondentes do ponto de consumo para o ponto de origem com o propósito de recapturar o valor ou destinar à apropriada disposição.

${ }^{3}$ Original: [...] como a área da logística empresarial que planeja, opera e controla o fluxo e as informações logísticas correspondentes do retorno dos bens de pós-venda e de pós-consumo ao ciclo de negócios ou ao ciclo produtivo, por meio dos canais de distribuição reversos, agregandoIhes valor de diversas naturezas: econômico, ecológico, legal, logístico, de imagem corporativa, entre outros. 
- Post-consumer Reverse Logistics: responsible for the flows of postconsumer waste to be increased to the production process or appropriate disposal.

- Reverse Logistics of Packaging: Responsible for packaging flows. Although included in the two above, there is a special attention due to the fact that a packaging has a significant cost in the productive process.

Within these three large areas of Reverse Logistics, are concentrated the activities as the illustration below.

Figure 1: Main Activities of Reverse Logistics

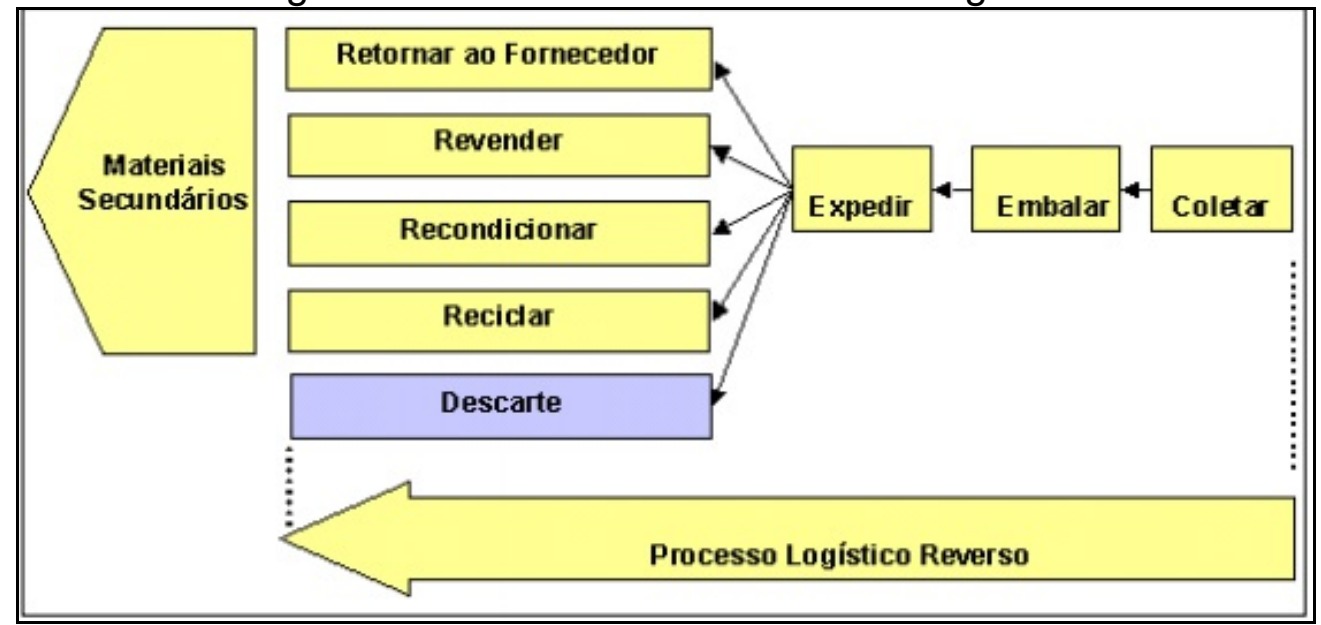

From: Lacerda, 2002.

Residues from establishments that centralize collections are directed to the following activities of the reverse process:

- Disposal: Waste that can't be recycled or those after a previous separation can't be reused and are directed to the ground according to the legal requirements;

- Recycling: Consumables that can be recycled are separated and directed to reprocessing and creating new products returning to the productive cycle of the same or another product.

- Reconditionnement: Possibility of products that can be reconditioned or repaired to be re-placed in the market. 
- Resell: There is also the possibility of resale of the inputs provided by Reverse Logistics to others suppliers who are dedicated to feed back the production cycle.

- Return to supplier: The return to the supplier is something constant within the systems of reverse logistics, mainly of packaging that return to the productive cycle.

Below is an illustration that shows how these activities work:

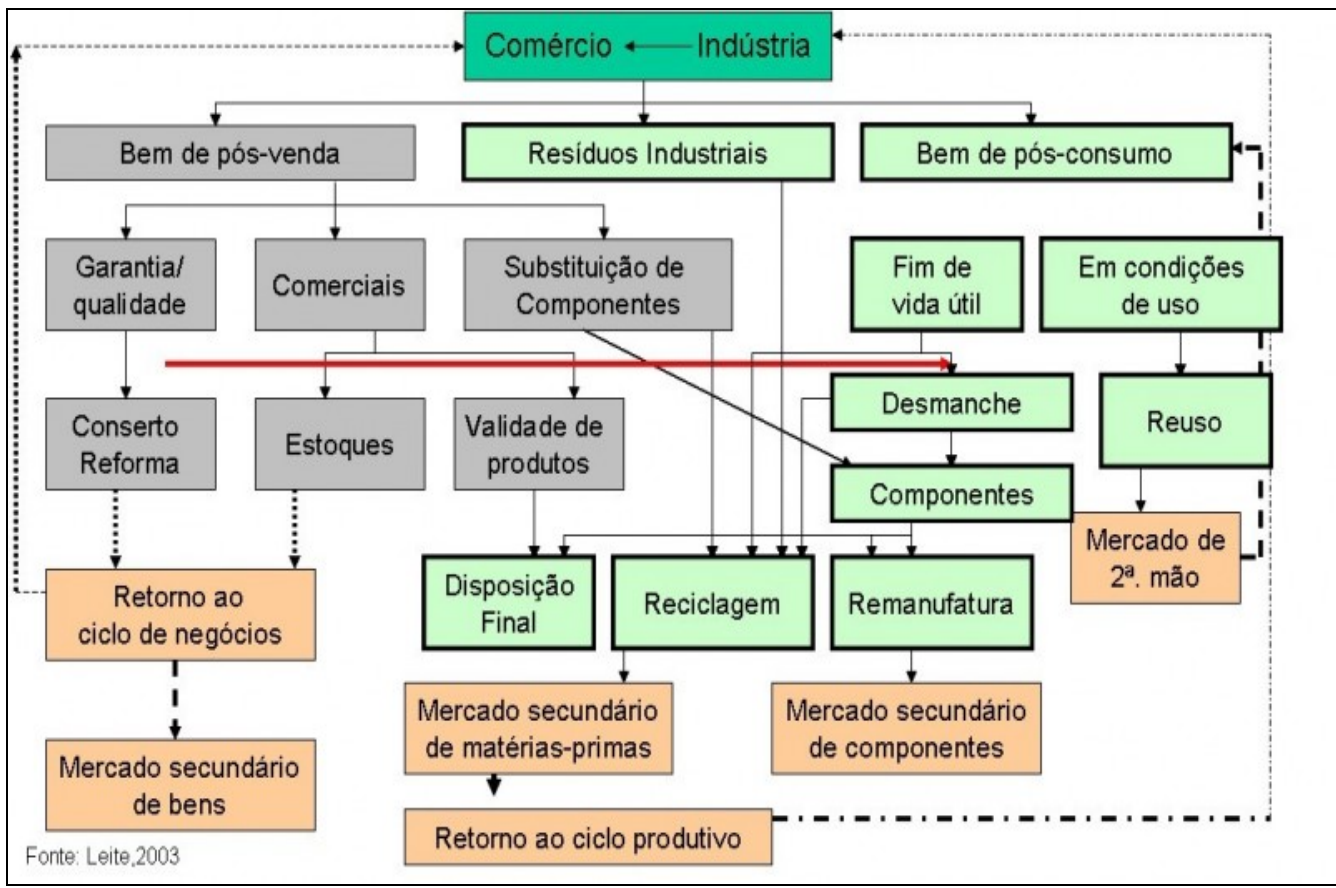

Figure 2: Focus of Reverse Logistics Activities From: Leite, 2003.

Currently in Brazil, there are several types of waste and packaging that are performed by the Reverse Logistics, but this article will focus on Reverse Logistics of lubricants packaging.

\section{PACKAGING OF LUBRICANTS AND RECYCLING}

Lubricant packaging are mostly made of a HDPE body (High Density Polyethylene) and its PP cap (Polypropylene Synthetic Polymer). According to the Federation of Industries of the State of São Paulo-FIESP (2007), HDPE is the second most recycled resin in the world.

According to the website "Tudo sobre Plástico" ("All About Plastic", our translation), HDPE has as its main characteristics the chemical resistance, the lower viscosity and the higher hardness that is the result of the manufacturing process. 
According to the product catalog of Hipermetal, others characteristics of HDPE are the low coefficient of friction, being weldable, easy to be moldable and can be printed and non-stick.

According to the information portal of the company Asta Química, HDPE, by its characteristics, is used mainly in cosmetic packaging, chemical and cleaning products, pipes for chemicals and gas products, and even fuel tanks for automotive vehicles. In the figure below, some HDPE packaging used for lubricant storage.

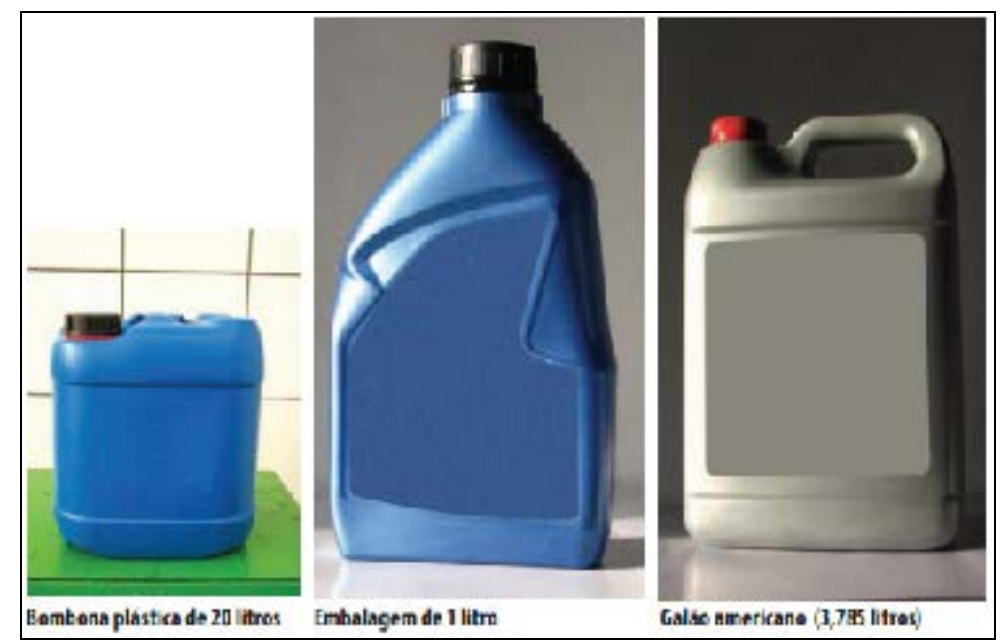

Figure 3: Types of HDPE Packaging - Lubricants From: FIESP, 2007.

The main packagings of HDPE are in models of $500 \mathrm{ml}$ and 1 liter, but also have bigger and smaller sizes according to the types of uses. For lubricants there is the use of larger bottles (20 Liters) for trucks, buses and vans, for example. Fluid packaging and additives in general have sizes between $200 \mathrm{ml}$ and $500 \mathrm{ml}$, because their use is not sporadic.

Recycling of plastic has been a recurring theme in the concerns with the future of the generations. HDPE, for example, despite being highly recyclable, recycling is still very low in Brazil. According to data from SINDIPLAST (Syndicate of the Plastic Material Industry of the State of São Paulo) in the FIESP report (2007), recycling of HDPE in 2004 was only $8.56 \%$ of the packaging produced.

The most common process for recycling HDPE is mechanical recycling. According to the site Techduto, after the separation of the packaging, they are ground, melted, cut and granulated. Below is a flowchart where you can check the steps of this process. 


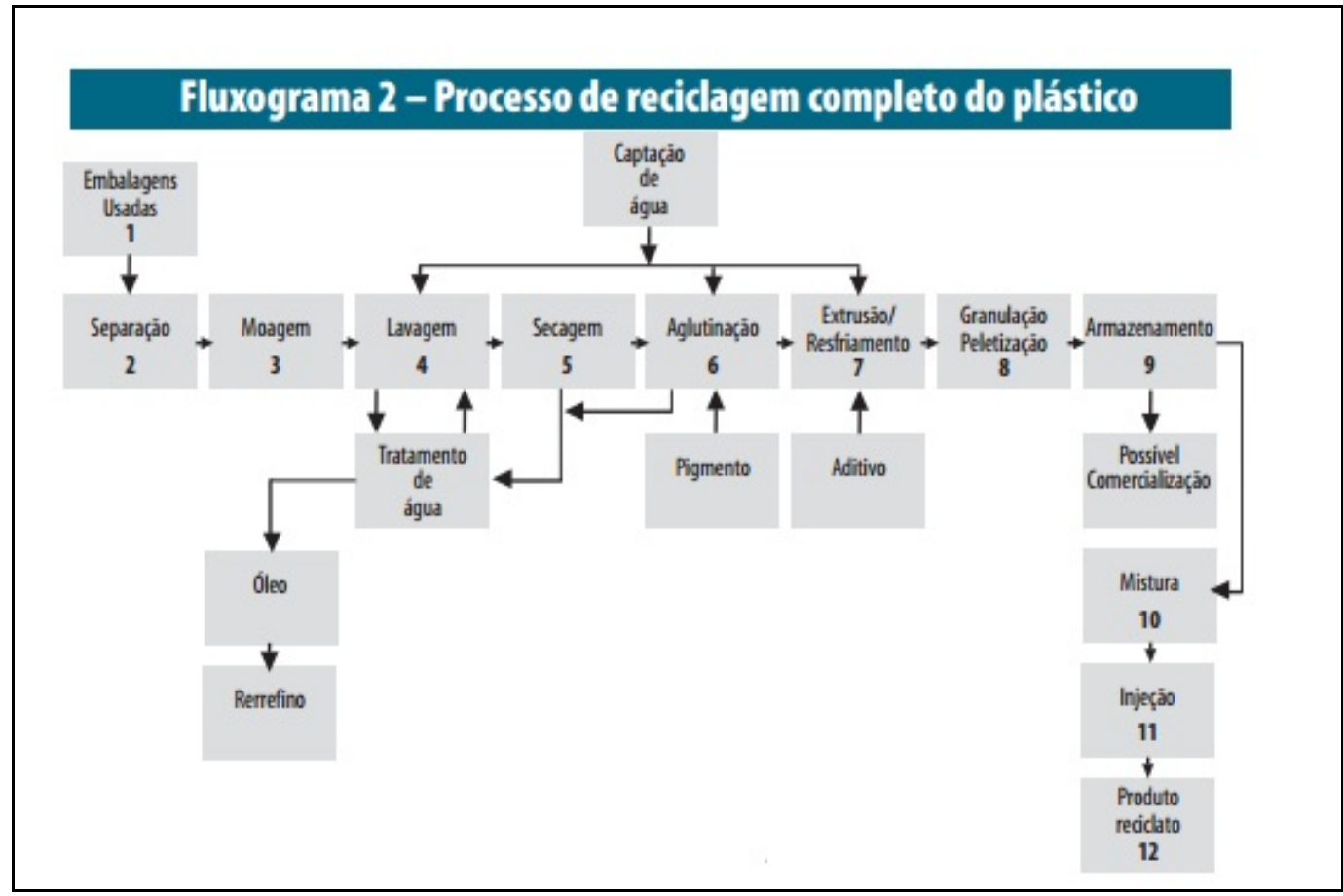

Figure 4: Plastic recycling process From: FIESP, 2007.

After separation, the HDPE packaging goes through a wash where the residues (lubricating oils) are separated for refining. After this, it passes through the drying, agglutination, extrusion and cooling to be granulated for later use.

Each plastic packaging has a symbology that indicates the type of plastic resin used in the packaging. According to the norm ABNT NBR 13230/2008, uses numbers from 1 to 7 involved on a triangle of three arrows according to the models below. What the HDPE indicates is number 2.

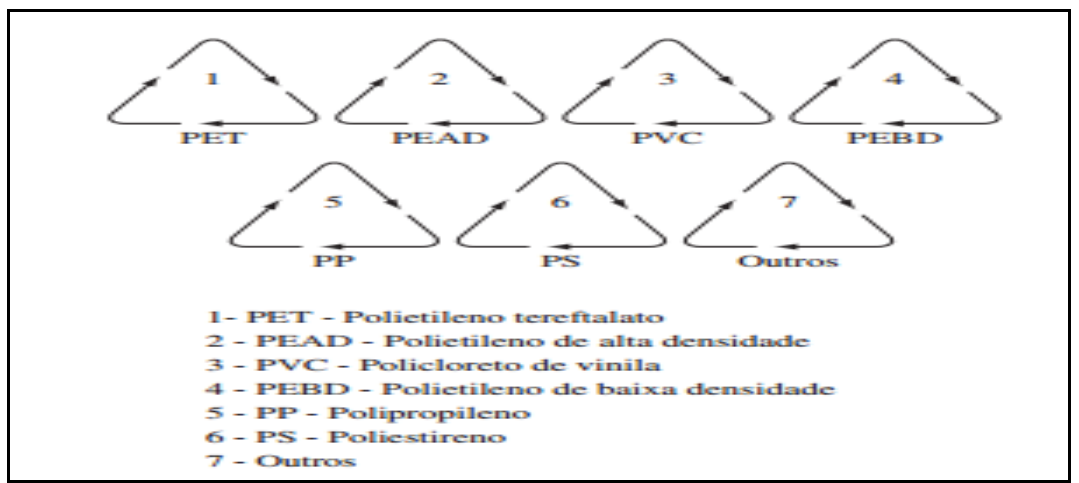

Figure 5: Symbology of Identification of Plastic Materials From: ABNT NBR 13230/2008.

The recycling of HDPE comes in Brazil, especially with the implementation of specific environmental legislation and a Reverse Logistics program that guarantees the collection of packaging, which will be dealt in the next chapters. 


\section{ENVIRONMENTAL LEGISLATION - NATIONAL SOLID WASTE POLICY}

The regulatory issues about the correct disposal of waste from lubricant packages and their debris have long been in Brazil. Unfortunately, it took time to regulate the issue and there are still major shortcomings to be demanded.

Since the 1990s, there have been major discussions about the subject in the country. The question of how to regulate the activity, separate the activities of refining of the contaminated lubricant, the recycling of the packaging and the responsibilities of each one of the agents involved in the chain were the questions demanded for the implementation of the current legislation.

In 1993, CONAMA (National Environment Council) determined in Resolution 09/1993 the procedures for the management of the used lubricating oil and its refinery. This resolution was updated through Resolution 362/2005 where CONAMA provided for the collecting, the collection and final destination of used or contaminated lubricating oil. It was regulated by ANP resolutions 125 to 130/99, where it regulated the activity of refining of used or contaminated oil in Brazil.

In CONAMA Resolution 362/2005, it was considered in accordance with ABNT NBR 10.004 that the lubricating oil used and its containers as hazardous waste due to its toxicity, and because of the potential risk of environmental damage, should have a different treatment for disposal and treatment. However, CONAMA's resolution was restricted only to the lubricating oil used, not considering the final destination of the packaging.

Finally, in 2010, the law 12.305/2010 was sanctioned, instituting the National Policy on Solid Waste. An advanced legislation, which contemplates the basic principles for a policy to elaborate initiatives for the correct disposal and reuse of debris, according to article 13 of the law, includes hazardous solid waste, which in accordance with ABNT NBR 10.004, including packaging.

The National Solid Waste Policy, in addition to disciplining the competencies of Federative entities, those involved in the product life cycle (manufacturers, importers, distributors, traders, customers) introduced the obligation of the implementation of Reverse Logistics systems to:

1. Agrochemicals and packaging; 
2. Piles and Batteries;

3. Tires;

4. Lubricating oils, waste and packaging;

5. Fluorescent lamps, sodium and mercury vapor lamps and mixed lamps;

6. Electronic products and their components.

The National Policy on Solid Waste was regulated by Law 7404/2010, which among other measures established the obligation of sectoral agreements with the Public Power to implement Reverse Logistics systems. In the next chapter will be approached the Jogue Limpo program, which was the result of the sector agreement in compliance with the legislation.

\section{JOGUE LIMPO PROGRAM}

The Jogue Limpo program started its activities in Rio Grande do Sul, in 2005, initially to comply with the state legislation of the SEMA/FEPAM 01/2003 Ordinance, the result of an agreement between environmental agencies and lubricant manufacturers.

There was a positive repercussion of the program that started an expansion. At 2008 it was implemented in Paraná and at 2010 in Santa Catarina. With the approval of the National Policy on Solid Waste and the construction of the Sector Agreement between the representatives of the manufacturers and resellers, the Ministry of the Environment started an expansion of the program.

By the end of 2015, the program was present in 3150 municipalities, 14 states and the Federal District. According to the Executive Director of the Jogue Limpo Institute, the program received about 4.700 tons of packaging. Today, the program is responsible for collection in gas stations, transporters, automotive centers, concessionaires, auto parts, supermarkets and wholesalers registered in the program.

Below, the figure 6 shows a graph that represents the participation of the retail distribution channels in the sale of lubricants in Brazil. The importance of understanding the Brazilian retail market is fundamental, because it is where there is a greater focus on the actions of the Jogue Limpo program. 


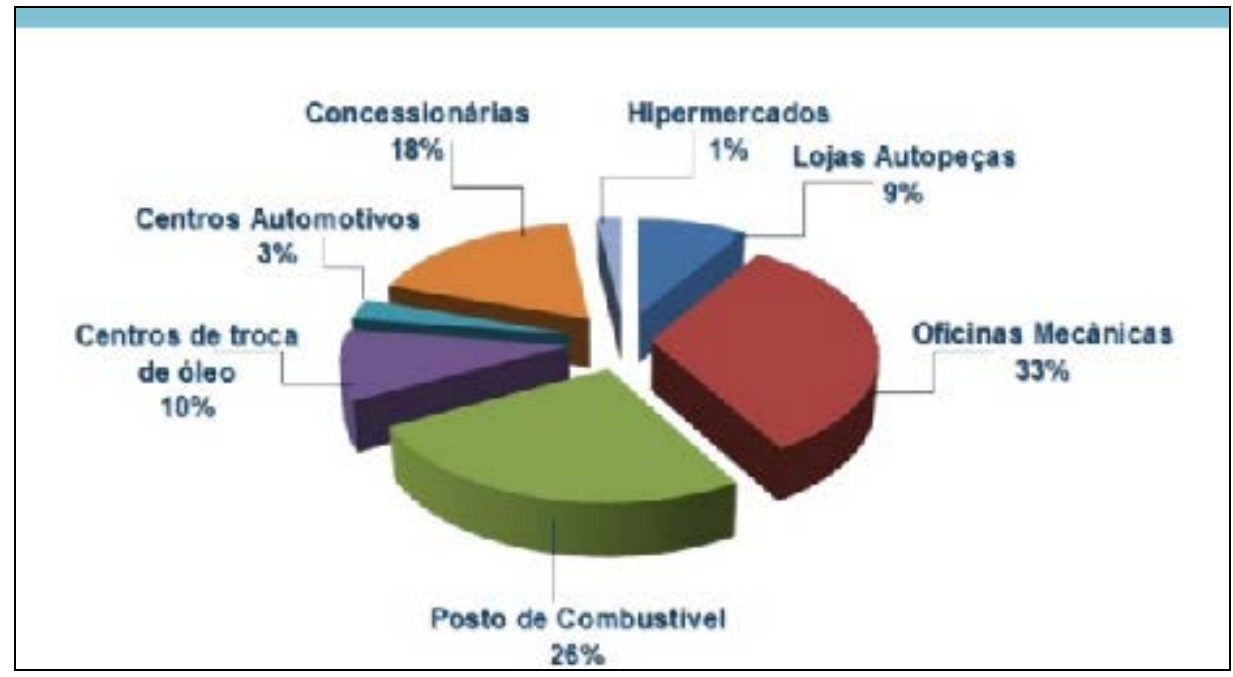

Figure 6: Distribution Channels Retailing of Lubricants in Brazil From: Sindicom/Jogue Limpo 2014.

With the approval of the sector agreement in 2012 between the Ministry of the Environment and SINDICOM (Syndicate National of Fuel and Lubricant Distribution Companies), the companies of the lubricants sector assumed shared responsibility with manufacturers, importers, distributors and retailers. According to the agreement provides that:

- Consumer: Return the used packaging to the dealer or distributor, preferably where it was purchased.

- Retail Trade / Retail / Distributor: Store correctly and make available to the Program Receipts;

- Manufacturers and Importer: Maintain a Reverse Logistics system, receive from the dealer or Distributor and make the process of recycling or correct disposal of the debris.

After the Industry Agreement, each state has a State agreement, where a compromise term is signed where there are the main goals and obligations of the agents involved. Each state makes a bid for the choice of the company that will be responsible for the collection and destination of the packaging. Below is an image that shows how the Jogue Limpo program works: 
DOI: 10.14807/ijmp.v8i5.602

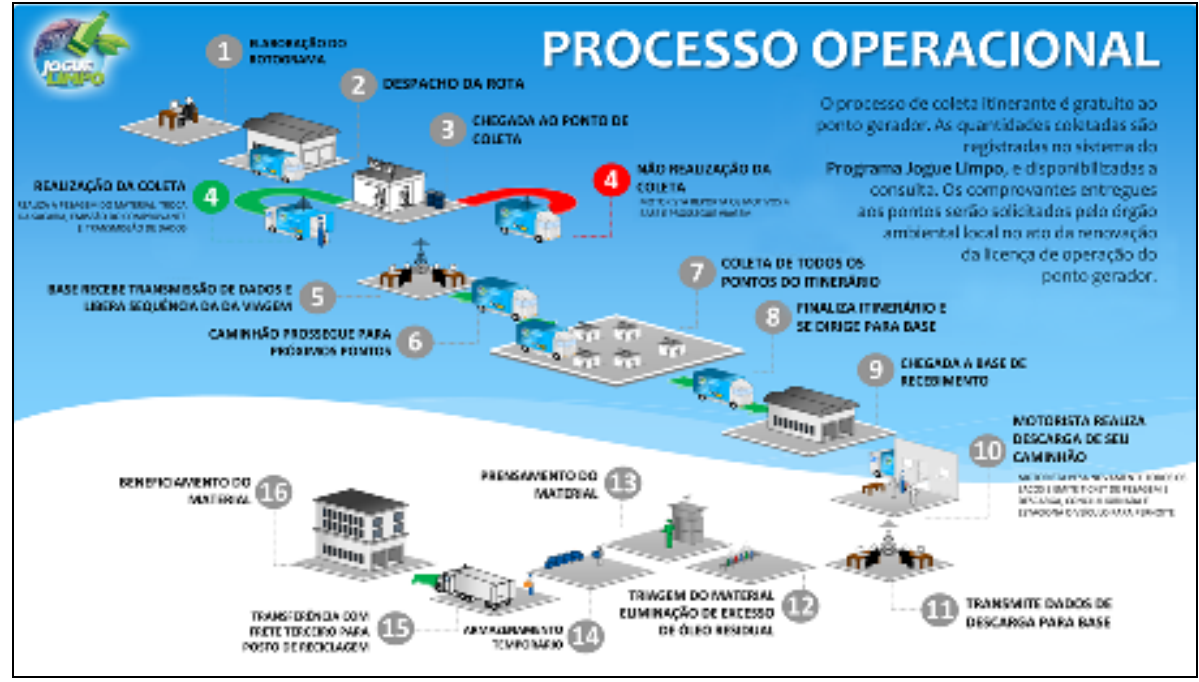

Figure 7: Collection Process of the Jogue Limpo Program

From: Jogue Limpo Program.

The trucks of the program leave the bases with the predetermined itinerary of establishment where the packaging will be collected. All trucks are trackable with GPS technology.

When arriving at the establishment the packaging must be collected after having the proper storage of the place. The amount of packaging is heavy and after the processing, a way of collection is left with the customer.

Below, the figure shows the form that should be stored in the packaging for later collection.
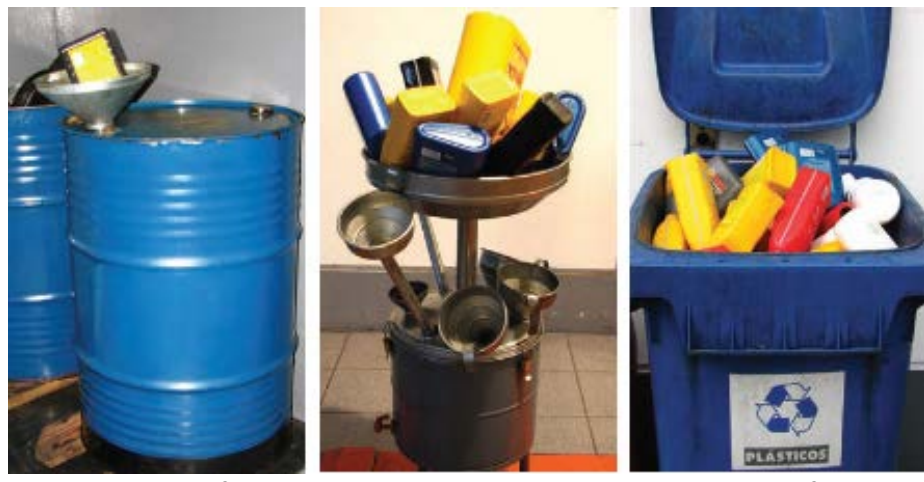

Figure 8: Flow of lubricating oil and separation of packaging From: FIESP, 2007.

After collection in the establishments, the trucks take the packaging to the Receiving Centers where the material is pressed and stored to be sent to the recycling process. 
DOI: 10.14807/ijmp.v8i5.602

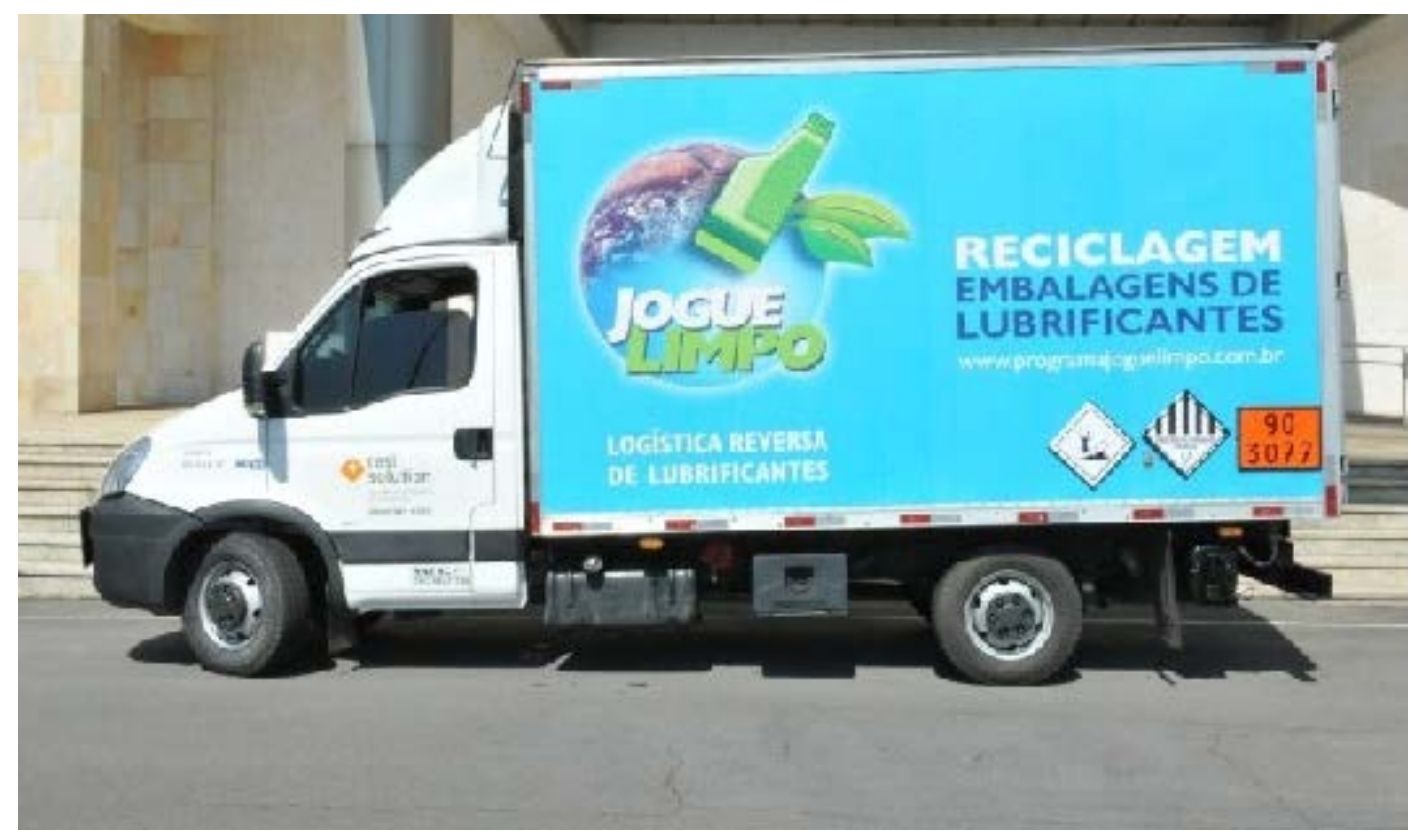

Figure 9: Truck of the Jogue Limpo Program

From: Jogue Limpo Program.

Today, the program has 23 collection centers, 69 trucks that make scheduled collections and 190 people that are employed in this process. More than 420 million packaging have been recycled since 2005, according to the program's website.

In addition to the reverse logistics of packaging used like lubricant, the Jogue Limpo program focuses on environmental education, raising children's awareness of the importance of recycling for sustainability. On the site of the program, several materials are aimed at the guidance of teachers and students about the environmental issue and the correct disposal of packaging.

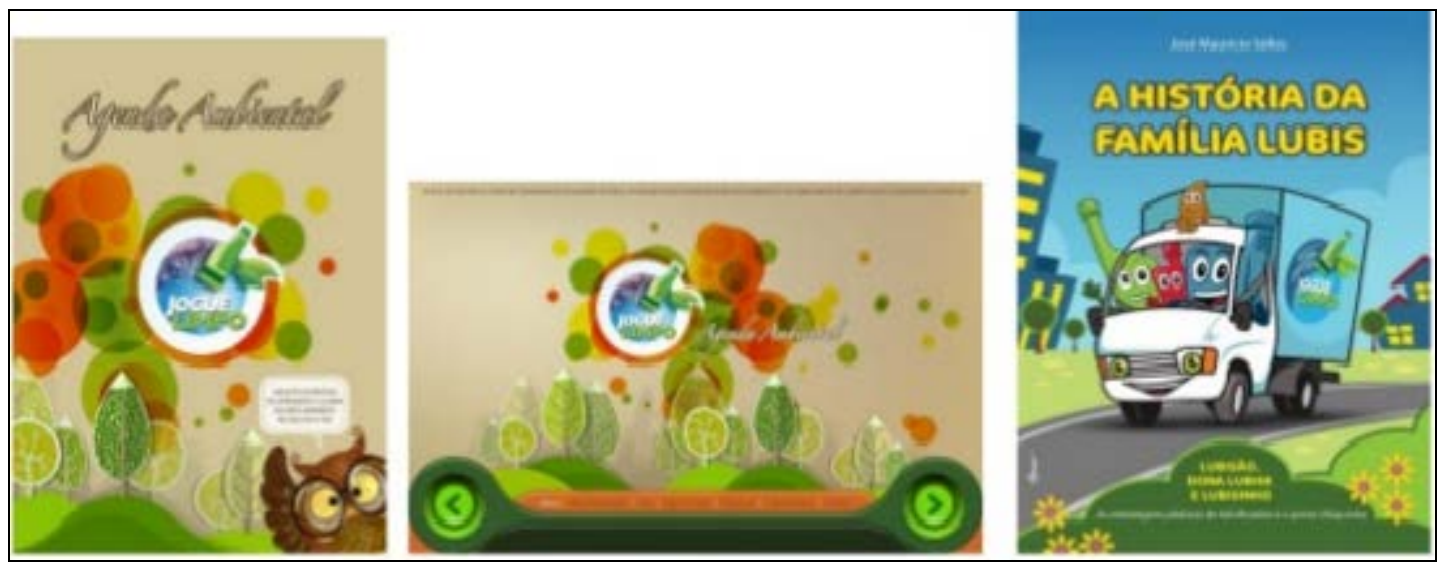

Figure 10: Educational Material From: Jogue Limpo Program.

Therefore, the Jogue Limpo program is being implemented in Brazil, and its future goal is to expand to the states of the Midwest and North of the country and in 
the states of Maranhão and Piauí, and the implementation of a new modeling in these states, called PEVs - Points of Voluntary Deliveries, instead of the collection system.

\section{DISCUSSION}

In Brazil, the sector responsible for the recycling processes of used packaging is still very small. It is necessary to encourage the recycling sector, because despite an advanced legislation, there are not incentives for the sector. The reduction of taxes could be a way to encourage the sector, since we are still crawling on the question recycling of many products.

Another important issue is to oblige manufacturers to develop a packaging traceability program, because this would bring greater results to the Jogue Limpo program, as well as being able to control the amount of packaging from which they are being recycled. This control will also guide decisions such as which packaging continues to produce, or how to effectively improve the distribution of products, for example.

Actions like Jogue Limpo are still limited, especially with regard to the forms of collections. The program should study new ways to collect packaging, adapt forms of collections according to locations and improve the efficiency of collections. PEVs (Points of Voluntary Deliveries) are an alternative, but there is a need for strategic plans and other solutions that increase collection capacity in remote regions.

The program can use environmental legislation as a way to help in articulating with the generating points. Improve communication with generating points, especially in communication for collection, since the registered establishment does not have access to the day of collection, for example, with communication with establishments, they can plan actions, improve the space for separation and accumulation of packaging.

The National Solid Waste Policy was essential for the introduction of the Reverse Logistics culture of waste, especially those listed in national legislation. They did not only create the Jogue Limpo program, but also some other companies specialized in this operation. However, there are still many conflicts with state and municipal legislations. There is a need for clearer environmental legislation, with more objective criteria. 
DOI: 10.14807/ijmp.v8i5.602

\section{FINAL CONSIDERATIONS}

The present article demonstrated through the Jogue Limpo program the importance of Reverse Logistics for the return and correct disposal of waste. Each day, whether due to government requirements or cost reduction, the company has expanded its collection of waste that is being used, mainly for reuse in the production process and this is the main purpose: generate value on what until a time was discarded and took many years for its decomposition into the environment.

Reverse Logistics is the means by which companies capture their waste and transform it into business opportunities. In addition to generating dividends, Reverse Logistics is responsible for new products, mainly due to the change of focus and the design of sustainable products, which are more easily returnable to their manufacturers.

Initiatives like the Jogue Limpo program are guiding to the expansion and accountability / awareness of other sectors of the Brazilian economy, about the need for Reverse Logistics introduced in its production processes. Initiatives such as Jogue Limpo will be replicated to other products.

However, despite the initiative being an important step, there are still many challenges. One of them is to create incentives to increase the collection of lubricant packaging. Many customers still do not have the environmental conscience to deliver empty containers in the stores, discarding them in an inappropriate place. Encouraging the customer through subsidies and benefits in fuel stations so that he would return to the establishment would be feasible for all involved.

Finally, the Jogue Limpo program is a very important initiative, but for it to be expanded, it is necessary the participation of all those involved in the product value chain, and the commitment of all parties to expand the program and increase the quantity of packaging collected. Reverse Logistics is the process that makes all these happen, but for this must be well planned and structured. One must think of all the constraints to achieve the programmed efficiency, and even if it is only at the beginning, you may already consider it satisfactory to arrive until here.

\section{REFERENCES}


AGÊNCIA NACIONAL DO PETRÓLEO, GÁS NATURAL E BIOCOMBUSTÍVEIS. (2015) Resolução ANP 125/ 99 a ANP 130/ 99. Brasília, DF, 1999. Available at: http://www.anp.gov.br. Accessed October 5.

ASSOCIAÇÃO BRASILEIRA DE NORMAS TÉCNICAS. (2008) NBR 13230:

simbologia indicativa de reciclabilidade e identificação de materiais plásticos. Rio de Janeiro.

ASSOCIAÇÃO BRASILEIRA DE NORMAS TÉCNICAS. (2004) NBR 10004: Resíduo Sólidos-Classificação. Rio de Janeiro.

BRASIL. (2010) Law No. 12.305/10, August 2, 2010. Establishes the National Policy on Solid Waste, amends Federal Law 9.605, of February 12, 1998 and provides others Provisions. Diário Oficial da União, Brasília, DF.

CARVALHO, J. M. C. (2002) Logística. 3a ed. Lisboa: Edições Silabo, 2002.

CONSELHO NACIONAL DO MEIO AMBIENTE. (1993) Resolution 03/1993. It establishes Environmental Procedures for the Management of Used or Contaminated Lubricating Oil-OLUC. Diário Oficial da União, Brasília, DF.

CONSELHO NACIONAL DO MEIO AMBIENTE. (2005) Resolution 362/2005. It provides for the collection and final disposal of used or contaminated lubricating oilOLUC. Diário Oficial da União, Brasília, DF, 2005.

FEDERAÇÃO DAS INDÚSTRIAS DO ESTADO DE SÃO PAULO. (2007) Reciclagem de embalagens plásticas usadas contendo óleo lubrificante. São Paulo: FIESP. Available at: http://www.crq4.org.br/downloads/embalagens.pdf. Accessed Octuber 19, 2015.

HIPERMETAL. Polietileno PEAD. Available at: http://www.hipermetal.com.br/site/produtos/plasticos_industriais/Polietileno.pdf. Accessed September 18, 2016.

LACERDA, L. (2002) Logística reversa: uma visão sobre os conceitos básicos e as práticas operacionais. Rio de Janeiro: COPPEAD/UFRJ.

LEITE, P. R. (2003) Logística Reversa: meio ambiente e competitividade. São Paulo: Prentice Hall.

LIVA, P. B. G.; PONTELO, V. S. L.; OLIVEIRA W. S. Logística Reversa. Available at: http://www.techoje.com.br/site/techoje/categoria/detalhe_artigo/301. Accessed September 18, 2016.

MOURA, R. A. (1989) Logística: suprimentos, armazenagem, distribuição física. Instituto de Movimentação e Armazenagem de Materiais. São Paulo.

PROGRAMA JOGUE LIMPO. Logística Reversa de Lubrificantes. Available at: http://www.joguelimpo.org.br/institucional/index.php/. Accessed September 18, 2016.

ROGERS, D.; TIBBEN-LEMBKE, R. (1998) Going backwards: reverse logistics trends and practices. Reno: University of Nevada.

TECHDUTO. Reciclagem PEAD: Características e Limitações. Available at: http://www.techduto.com.br/reciclagem-pead/. Accessed September 18, 2016.

YIN, R. (2001) Estudo de caso - planejamento e métodos. $2^{\mathrm{a}}$ ed. Porto Alegre: Bookman. 